\title{
A case of eosinophilic esophagitis, with sensitization to BSA (meat allergy) and rhinoconjunctivitis due to dog epithelium
}

\author{
L Vazquez Fuertes ${ }^{1 *}$, M Perez Bustamante 1 , A Bueso Fernandez ${ }^{1}$ A Gonzalez Pino², F Pineda De La Losa ${ }^{3}$ \\ From Food Allergy and Anaphylaxis Meeting (FAAM 2013) \\ Nice, France. 7-9 February 2013
}

\section{Background}

Patients with eosinophilic esophagitis (EEo) have a prior history of atopy. Skin prick test(SPT) is able to identify the allergens involved, allowing a correct dietary approach, in order to achieve the remission of sympthoms and discontinue swallowed costicostheroids. Allergy to bovine meat and especially to Bovine serum albumin (BSA) is exceptional in adult life, but can be a cause of EEo.

\section{Methods}

We present one 26-year-old patient with EEo diagnosed six months before, who presented characteristic sympthoms after eating mamal's meat (well cooked beef and pork), and legumes (chickpea), as food impactation. She had history of rhinitis, related to sensitization to dog epithelium. The patient underwent SPT, specific IgE detection and SDS-PAGE immunoblotting studies.

\section{Results}

The SPT with food allergens showed negative responses to pork, cow, rabbit, lamb, chicken meat, milk, egg, legumes (including chickpea), nuts, fruits and vegetables, fish, seafood, cereals. It showed positive result to BSA. The SPT with aeroallergens showed negative responses to all we studied, but dog epithelium that was positive. The determination of specific IgE were negative to beef and pig meat,milk,egg, legumes, nuts, cereals. The result was positive to dog epithelium (17.1 ku/l CAP), dog BSA
(8.03 ku/l), cow BSA $(0.51 \mathrm{ku} / \mathrm{l})$. Total IgE 214UI/l.IgEImmunoblotting indicates recognition bands of 60-70 $\mathrm{kDa}$ components (molecular weight compatible with BSA) in dog epithelium extract, and less intensity response in meat extracts. Two allergens with a molecular weight close to $15-20 \mathrm{kDa}$ were recognized. We found reactivity to $40-45 \mathrm{KDa}$ allergens in meat extract also.

\section{Conclusion}

We report a case of EEo, who had sensitization to BSA and dog epithelium. The patient suffered previous rhinoconjunctivitis related to her dog, but we could not demonstrate cross-reactivity. It is suggested a potential inciting role for aeroallergens in patient with EEo, and the subsequent food allergy. BSA is an approximately 67 $\mathrm{KDa}$ protein involved both in milk (especially in children) and beef allergy. It explains cross-reactivity among different meats and epitheliums and different mammal's meat. In our case, the patient's serum recognized a protein with a molecular weight of $17 \mathrm{kDa}$, that could correspond to myoglobin, a heat-resistant protein that explains why some patients do not tolerate undercooked or even cooked meat. Thank our study, the patient could discontinued swallowed corticosteroids and avoidance diet, but meats.

\section{Disclosure of interest}

None declared.

${ }^{1}$ Allergy, Torrejon Hospital, Madrid, Spain

Full list of author information is available at the end of the article

(c) 2013 Fuertes et al; licensee BioMed Central Ltd. This is an Open Access article distributed under the terms of the Creative Commons 


\section{Author details}

${ }^{1}$ Allergy, Torrejon Hospital, Madrid, Spain. ${ }^{2}$ Gastroenterology, Torrejon

Hospital, Madrid, Spain. ${ }^{3}$ Laboratory Department, Diater Laboratory, Madrid,

Spain.

Published: 25 July 2013

doi:10.1186/2045-7022-3-S3-P166

Cite this article as: Fuertes et al:: A case of eosinophilic esophagitis,

with sensitization to BSA (meat allergy) and rhinoconjunctivitis due to dog epithelium. Clinical and Translational Allergy 2013 3(Suppl 3):P166.

Submit your next manuscript to BioMed Central and take full advantage of:

- Convenient online submission

- Thorough peer review

- No space constraints or color figure charges

- Immediate publication on acceptance

- Inclusion in PubMed, CAS, Scopus and Google Scholar

- Research which is freely available for redistribution

Submit your manuscript at 